\title{
Antibody levels to parainfluenza, herpes simplex, varicella-zoster, cytomegalo virus, and measles virus in patients with connective tissue diseases
}

\author{
J. L. KALLIOMÄKI AND PEKKA HALONEN \\ From the Department of Medicine and the Department of Virology, University of Turku, Turku, Finland
}

Phillips and Christian (1969) reported that measles antibody titres are higher in patients with systemic lupus erythematosus (SLE) than in controls. Later (1970) they also found increased levels of antibody titres to parainfluenza type 1 virus in patients with SLE and in six patients with Reiter's syndrome, but the mean titres of patients with rheumatoid arthritis (RA) were not significantly different than those of normal subjects.

The present report describes the antibody titres to parainfluenza type 1 , herpes simplex, varicella-zoster, cytomegalo virus and measles virus in 48 patients with connective tissue diseases and in 48 normal subjects. The antibody survey of measles virus was carried out with complement fixation (CF), haemagglutination inhibition $(\mathrm{HI})$, and inhibition of saltdependent haemagglutination (SDI).

\section{Subjects and methods}

The serum specimens were collected from 48 consecutive patients with connective tissue diseases. The number of patients in each diagnostic subgroup is shown in Table I. In 26 patients RA was classical or definite; one also had dermatitis herpetiformis and four with classical disease had chronic nephropathy. The SLE patients had been treated several times at our hospital and the diagnosis was confirmed. The postinfective arthritis group contained four patients with Yersinia enterocolitica infection and one with salmonellosis, and in one patient the disease developed after an influenzalike disease.

The serum specimens of the control subjects were the same specimens as those which were used as controls in a large seroepidemiological study of multiple sclerosis (Panelius, Kivalo, Rinne, Halonen, Penttinen, and Salmi, 1971). They were collected from normal healthy subjects

Table I Geometric titres mean of parainfluenza type 1, herpes simplex, varicella-zoster, and cytomegalo tirus CF antibody in 48 patients with connective tissue disease and in 48 healthy controls

\begin{tabular}{|c|c|c|c|c|c|c|}
\hline Group & $\begin{array}{l}\text { No. of } \\
\text { subjects }\end{array}$ & Parainfluenza & & $\begin{array}{l}\text { Herpes } \\
\text { simplex }\end{array}$ & Varicella-zoster & Cytomegalo rirus \\
\hline RA & 25 & $7 \cdot 2$ & & $7 \cdot 2$ & $6 \cdot 4$ & $8 \cdot 0$ \\
\hline SLE & 9 & $5 \cdot 4$ & & $7 \cdot \overline{4}$ & $4 \cdot 7$ & $13 \cdot 7$ \\
\hline Postinfective arthritis & 6 & $22 \cdot 6$ & & $12 \cdot 7$ & $6 \cdot 4$ & $14 \cdot 3$ \\
\hline Ankylosing spondylitis & 3 & $10 \cdot 1$ & & $16 \cdot 0$ & $6 \cdot 4$ & $20 \cdot 6$ \\
\hline Dermatomyositis & 2 & $8 \cdot 0$ & & $16 \cdot 0$ & $4 \cdot 0$ & $22 \cdot 6$ \\
\hline Arthritis with sarcoidosis & 1 & 16 & & 16 & -16 & 16 \\
\hline Reiter's syndrome & 1 & 32 & & 32 & 16 & 16 \\
\hline Arthritis NUD & 1 & 32 & & 64 & 16 & 16 \\
\hline Controls & 48 & $6 \cdot 3$ & & $23 \cdot 0$ & $4 \cdot 6$ & $7 \cdot 8$ \\
\hline
\end{tabular}

\begin{tabular}{lll}
\hline Herpes simplex CF $:$ & RA/Controls & P 0.005 \\
& SLE/Controls & Not significant \\
RA SLE/Controls & P 0.001 \\
& All patient groups/Controls & P 0.001
\end{tabular}

Other differences are not significant. 
living in the same area as the patients. The age distribution of both groups was similar.

In all serological tests a microtechnique was used (Sever, 1962; Panelius, 1969). The antigens for measles CF, HI, and SDI were prepared in Vero cells, parainfluenza type $1 \mathrm{CF}$ antigen in embryonated eggs, and cytomegalo virus $\mathrm{CF}$ antigen in primary trypsinized human embryonic fibroblast cultures. The varicella-zoster antigen was kindly supplied by Dr. Arne Svedmyr, Central Bacteriological Laboratory, Stockholm, Sweden.

For the HI and SDI tests, serum specimens were adsorbed with kaolin and then with monkey erythrocytes.

The differences between the titre values were analysed by Student's t-test.

\section{Results}

The geometric mean titres of parainfluenza type 1 , herpes simplex, varicella-zoster and cytomegalo virus $\mathrm{CF}$ antibody in each diagnostic subgroup and in the controls are shown in Table II. The herpes simplex CF antibody titres were significantly lower $(P<0.05)$ in the RA group than in the control subjects. The slightly increased mean titre of parainfluenza type 1 antibody in the group of postinfective arthritis was mainly caused by one specimen in which the titre was $1: 512$.

With each of the three serological tests used for measuring measles antibody (Table II), a tendency was found to higher titres in the patients than in the healthy controls. The most significantly higher titres were seen in patients with SLE (HI: $\mathrm{P}<0.001$; CF : $\mathbf{P}<0.02$; SDI: $\mathbf{P}<0.05$ ). The measles antibody titres were also statistically significantly higher $(\mathrm{P}<0.001)$ with $\mathrm{CF}$ and $\mathrm{HI}$ techniques in the RA group than in the controls, but the difference was insignificant with the SDI technique.

The number of specimens was too small in the other diagnostic subgroups for statistical analysis, but the two patients with dermatomyositis and one patient with Reiter's syndrome had higher titres in each test than the mean value of the controls.

The highest measles CF titre in the whole series was $1: 512$, which was found in three specimens in the RA group, in one of the postinfective group, in none of the SLE group, and in one of the controls. The highest HI titre was 1:1,280; this was found only in two specimens of the RA group and two of the SLE group. The highest titre in the SDI test was 10,240, which was found in two specimens of the RA group, in one of the SLE group, and in one of the controls (Table IV). The rate of specimens with high titres (CF $\geqq 128 ; \mathrm{HI} \geqq 320 ; \mathrm{SDI} \geqq 640$ ) was considerably greater in the SLE than in the RA group, but was greater in the latter than in the healthy controls (Table III, overleaf).

The results of the HI and SDI tests usually correlated, but in a number of specimens the CF titres were not in agreement with the HI and SDI titres (Table IV, overleaf).

\section{Discussion}

The results of the present study confirm the earlier finding of Phillips and Christian (1969) indicating a significantly higher mean titre of measles $\mathrm{HI}$ antibody in serum specimens from SLE patients than in those from healthy control subjects. Our results also suggest that higher measles antibody titres can be found in patients with RA, but the numbers of patients with postinfective arthritis, ankylosing spondylitis, and dermatomyositis were too small for statistical analysis. Since Phillips and Christian also demonstrated significantly higher measles $\mathrm{HI}$ titres in patients with Reiter's syndrome, the increased measles titres may

Table II Geometric mean titres of measles antibody measured with complement fixation (CF), haemagglutination inhibition $(H I)$, and inhibition of salt-dependent haemagglutination $(S D I)$ in patients with connective tissue disease and healthy controls

\section{Group}

RA

SLE

Postinfective arthritis

Ankylosing spondylitis

Dermatomyositis

Reiter's syndrome

Arthritis with sarcoidosis

Arthritis NUD

\begin{tabular}{|c|c|c|c|c|c|}
\hline Con & trols & & 4 & 8 & $13 \cdot 1$ \\
\hline CF: & $\begin{array}{l}\text { RA } \\
\text { SLE } \\
\text { RA + SLE } \\
\text { All patient groups }\end{array}$ & $\begin{array}{l}\mathbf{P}<0.001 \\
\mathbf{P}<0.02 \\
\mathbf{P}<0.01 \\
\mathbf{P}<0.01 \\
\text { I: } \quad \text { SLE P } \\
\text { Other d }\end{array}$ & $\begin{array}{l}\text { HI : } \\
0.05 \\
\text { erence }\end{array}$ & $\begin{array}{l}\text { RA } \\
\text { SLE } \\
\text { RA + SLE } \\
\text { All patient groups } \\
\text { es not significant }\end{array}$ & $\begin{array}{l}\mathbf{P}<0.01 \\
\mathbf{P}<0.001 \\
\mathbf{P}<0.005 \\
\mathbf{P}<0.005\end{array}$ \\
\hline
\end{tabular}


Table III Number of specimens with increased level of CF antibody ( $\geqq 128)$ to parainfluenza type 1, herpes simplex, varicella-zoster $(V-Z)$, cytomegalo virus, and measles virus in patients with connective tissue disease and in control subjects, and the number of specimens with increased level of $H I(\geqq 320)$ and $S D I(\geqq 640)$ antibody to measles virus

\begin{tabular}{|c|c|c|c|c|c|c|c|c|}
\hline \multirow{2}{*}{ Group } & \multirow{2}{*}{$\begin{array}{l}\text { No. of } \\
\text { subjects }\end{array}$} & \multirow{2}{*}{$\begin{array}{l}\text { Para- } \\
\text { influenza } \\
\text { CF }\end{array}$} & \multirow{2}{*}{$\begin{array}{l}\text { Herpes } \\
\text { simplex } \\
C F\end{array}$} & \multirow{2}{*}{$\begin{array}{l}V-Z \\
C F\end{array}$} & \multirow{2}{*}{$\begin{array}{l}\text { Cyto- } \\
\text { megalo virus } \\
\text { CF }\end{array}$} & \multicolumn{3}{|l|}{ Measles } \\
\hline & & & & & & $C F$ & $H I$ & $S D I$ \\
\hline RA & 25 & 0 & 0 & 0 & 0 & $7(27 \%)$ & $4(15 \%)$ & $3(12 \%)$ \\
\hline SLE & 9 & 0 & 0 & 0 & 1 & $4(44 \%)$ & $5(56 \%)$ & $5(56 \%)$ \\
\hline Postinfectious arthritis & 6 & 1 & 0 & 0 & 0 & $1(17 \%)$ & $1(17 \%)$ & 0 \\
\hline Ankylosing spondylitis & 3 & 0 & 0 & 0 & 0 & 1 & 0 & 0 \\
\hline Dermatomyositis & 2 & 0 & 0 & 0 & 0 & 1 & 0 & 0 \\
\hline Reiter's syndrome & 1 & 0 & 0 & 0 & 0 & 1 & 0 & 1 \\
\hline Arthritis with sarcoidosis & 1 & 0 & 0 & 0 & 0 & 0 & 0 & 0 \\
\hline Arthritis NUD & 1 & 0 & 0 & 0 & 0 & 0 & 0 & 0 \\
\hline Controls & 48 & $\mathbf{0}$ & 3 & 1 & 0 & $4(8 \%)$ & $4(8 \%)$ & $5(10 \%)$ \\
\hline
\end{tabular}

Table IV Representative results of measles CF, HI, and SDI tests in serum specimens of patients and controls with increased titres

\begin{tabular}{|c|c|c|c|c|}
\hline \multirow{2}{*}{ Subject no. } & \multirow{2}{*}{ Diagnosis } & \multicolumn{3}{|c|}{ Measles } \\
\hline & & $C F$ & $H I$ & $S D I$ \\
\hline $\begin{array}{r}2 \\
5 \\
6 \\
8 \\
11 \\
16 \\
18 \\
20 \\
43\end{array}$ & $\begin{array}{l}\text { RA } \\
\text { SLE } \\
\text { Healthy control } \\
\text { RA } \\
\text { RA } \\
\text { SLE } \\
\text { Reiter's syndrome } \\
\text { Healthy control } \\
\text { RA }\end{array}$ & $\begin{array}{r}522 \\
128 \\
64 \\
256 \\
256 \\
128 \\
128 \\
16 \\
16\end{array}$ & $\begin{array}{r}1,280 \\
1,280 \\
320 \\
320 \\
40 \\
1,280 \\
160 \\
640 \\
1,280\end{array}$ & $\begin{array}{r}10,240 \\
2,560 \\
160 \\
2,560 \\
20 \\
10,240 \\
640 \\
160 \\
10,240\end{array}$ \\
\hline
\end{tabular}

be found in patients with many types of connective tissue disease. Our results indicate that the higher measles titres are demonstrable also with the CF and SDI techniques though to a lesser degree.

The greater difference in measles $\mathrm{HI}$ titres between the RA group and the controls in the present study than in that of Phillips and Christian (1970) may be partly explained by diagnostic differences. In our RA group no kidney biopsy specimens were taken and it is possible that some of the patients had SLE in addition to definite or classical RA. No increased antibody titres to parainfluenza type 1 virus were demonstrated in any of the diagnostic groups, but the measurement of antibody was done by a CF technique instead of the $\mathrm{HI}$ technique.

What is the significance of the increased measles antibody titres in SLE and probably in other connective tissue diseases? Phillips and Christian (1970) have suggested three possible explanations:

(1) Persistent measles virus infection together with the immunological hyper-reactivity in SLE which could stimulate an increased antibody formation against measles virus antigens.

(2) The immunological hyper-reactivity could stimulate nonspecifically from the production of measles as well as other antibodies.
(3) Autoantibodies in SLE may cross-react with a host antigen on the viral membrane.

The authors' conclusions were not definite but they pointed out other data which were compatible with the first hypothesis. One was the aetiology of subacute sclerosing panencephalitis (SSPE), which is an example of persistent or latent infection with measles virus. Microtubular structures and endothelial cytoplasmic inclusions similar to the nucleoprotein demonstrated in electron micrographs of brain cells of SSPE patients have been demonstrated in renal tissue and in the walls of the arterioles of SLE patients (Fresco, 1968, 1970; Grausz, Earley, Stephens, Lee, and Hopper, 1970). The only significant correlation of measles antibody titre with clinical or laboratory parameters was that with serum gamma globulin in a series of Phillips and Christian (1971), which suggests that increases in viral antibody in SLE result from generalized immunological hyperreactivity.

In this connection, the findings of Grayzel and Beck (1970) are of great interest. They demonstrated that cell cultures of rheumatoid synovial membranes were resistant to a growth of rubella virus while those of nonrheumatoid membranes were not. The resistance was not mediated by interferon and no infectious 
virus could be cultivated from the medium or cells of uninoculated cultures of synovial membranes. However, harvesting infectious virus from cell cultures harbouring latent or incomplete virus requires prolonged cultivation with a series of passages and other specified culture conditions as was clearly demonstrated by experience with SSPE (Horta-Barbosa, Fuccillo, Sever, and Zeman, 1969; Payne, Baublis, and Itabashi, 1969).

An additional finding which should be pointed out is the decreased rate of RA in patients with multiple sclerosis, another disease in which measles antibody titres are increased (Panelius, Salmi, Halonen, and Penttinen, 1971).

In the present study the mean titres of herpes simplex virus were three times lower in the RA group (7.2) and in the SLE group (7.4) than in the controls $(23 \cdot 0)$ and the rates of positive $(\geqq 16)$ specimens in these groups were 36,33 , and 90 per cent. respectively. The decrease in herpes simplex CF titres in patients with RA was described by Smiley and Casey (1969). These unexpected findings may be connected with the recent observations of Ashe, Daniels, Scott, and Notkins (1971) indicating the attachment of rheumatoid factor to infectious herpes simplex virus antibody complexes resulting in inactivation of infectivity.

Continuously developing virus-antibody com- plexes in persistent or latent virus infections may be intimately connected with the pathogenesis of RA, SLE, and other diseases of connective tissue.

\section{Summary}

The CF antibody titres to parainfluenza type 1 , herpes simplex, cytomegalo virus, varicella-zoster, and measles virus and the HI and SDI titres to measles virus were measured in 48 patients with connective tissue disease and in $\mathbf{4 8}$ healthy subjects. The geometric mean titres to measles virus were higher in nine patients with systemic lupus erythematosus than in 25 patients with rheumatoid arthritis, but in the latter the mean titres were higher than in healthy controls. The differences in titres were more significant with the HI than with the CF or SDI test. The proportion of patients with high measles antibody titres was higher in patients with SLE and slightly higher in patients with RA than in the controls. No significant differences in the mean titres to parainfluenza, varicella-zoster, or cytomegalo virus were found between the patients and the controls. The mean titres of herpes simplex CF antibody were three times lower in patients with RA and with SLE than in healthy controls.

\section{References}

Ashe, W. K., Daniels, C. A., Scott, G. S., AND Notkins, A. L. (1971) Science, 172, 176 (Interaction of rheumatoid factor with infectious herpes simplex virus-antibody complexes)

Fresco, R. (1968) Fed. Proc., 27, 246 (Tubular (myxovirus-like) structures in glomerular deposits from a case of lupus nephritis)

(1970) New Engl. J. Med., 283, 1231 (Virus-like particles in systemic lupus erythematosus)

Grausz, H., Earley, L. E., Stephens, B. G., Lee, J. C., AND HopPer. J., JR (1970) Ibid., 283, 1233 (Correspondence)

GraYZEL, A. I., AND BECK, C. (1970) J. exp. Med. , 131, 367 (Rubella infection of synovial cells and the resistance of cells derived from patients with rheumatoid arthritis)

Horta-Barbosa, L., FuCCILO, D. A., Sever, J. L., AND Zeman, W. (1969) Nature (Lond.), 221, 974 (Subacute sclerosing panencephalitis: Isolation of measles virus from a brain biopsy)

Panelius, M. (1969) Acta neurol. scard., 45, Suppl. 39 (Studies on epidemiological, clinical and etiological aspects of multiple sclerosis)

- Kivalo, E., Rinne, U. K., Halonen, P., Pentrinen, K., and Salmi, A. A. (1971) 'XIII European Symposium on Poliomyelitis and Other Virus Diseases', in press (Virus antibodies in patients with multiple sclerosis compared with two control groups)

- Salmi, A. A., Halonen, P., And Pentrinen, K. (1971) Acta neurol. scand., in press (Measles antibodies detected with various techniques in patients with multiple sclerosis)

Payne, E. F., Baublis, J. V., AND Itabashi, H. H. (1969) New Engl. J. Med., 281, 585 (Isolation of measles virus from cell cultures of brain from patient with subacute sclerosing panencephalitis)

Phillips, P. E., And Christian, C. L. (1969) Arthr. and Rheum., 12, 688 (Virologic studies in systemic lupus erythematosus).

- - (1970) Science, 168, 982 (Myxovirus antibody increases in human connective tissue disease)

_- - (1971) 'Abstr. of VII European Rheum. Congr., Brighton', 21.3 (Virus studies in connective tissue diseases)

SEVER, J. L. (1962) J. Immunol., 88, 320 (Application of a microtechnique to viral serological investigations)

Smiley, J. D., AND CASEY, H. L. (1969) Arthr. and Rheum., 12, 698 (Decreased CF antibodies in sera and decreased lymphocyte transformation to herpes simplex in patients with rheumatoid arthritis) 